\title{
Clostridium haemolyticum
}

National Cancer Institute

\section{Source}

National Cancer Institute. Clostridium haemolyticum. NCI Thesaurus. Code C86281.

A species of anaerobic, Gram positive, rod shaped bacteria assigned to the phylum

Proteobacteria. This species is motile, produces the type $\mathrm{G}$ toxin and is hemolytic. C.

haemolyticum is found in soil and water and is pathogenic, being the causative agent of Red Water disease in grazing animals. 